\title{
Modeling and Optimization Techniques of Electronic Devices Using Genetic Algorithm
}

\author{
Sherif Michael \\ Department of Electrical and Computer Engineering, Naval Postgraduate School, Monterey, California, USA
}

\begin{abstract}
A new method for developing a realistic physical model of any type of solid state device is presented. Application to model advanced multi-junction solar cells; Thermophotovoltaics; sensors; as well as other novel solid state devices are introduced in this presentation. The primary goal of multijunction solar cell design is to maximize the output power for a given solar spectrum [1-4]. The construction of multijunction cells places the individual junction layers in series, thereby limiting the overall output current to that of the junction layer producing the lowest current [5-7]. The solution to optimizing a multijunction design involves both the design of individual junction layers which produce an optimum output power and the design of a series-stacked configuration of these junction layers which yields the highest possible overall output current. This paper demonstrates the use of Genetic Algorithm in a two-part process to refine a given multijunction solar cell design for near-optimal output power for a desired light spectrum. This approach can similarly be utilized to optimize the parameters of any Solid state device to yield any desired performance.
\end{abstract}

Keywords: modeling, solar cells, photovoltaics, optimizations, genetic algorithm

\section{Introduction}

The optimization routines described in this paper use a solar cell model developed earlier at the Naval Postgraduate School (NPS) using the ATLAS device simulator by SILVACO International [8]. This model accurately predicts the electrical characteristics of a solar cell based on virtual fabrication of its physical structure.

As an example, an $\mathrm{InGaP} / \mathrm{GaAs} / \mathrm{Ge}$ triple-junction solar cell is modeled, and the device lightinduced photogeneration, along with the corresponding spectral response of each layer, are illustrated in Figures 1 and 2.
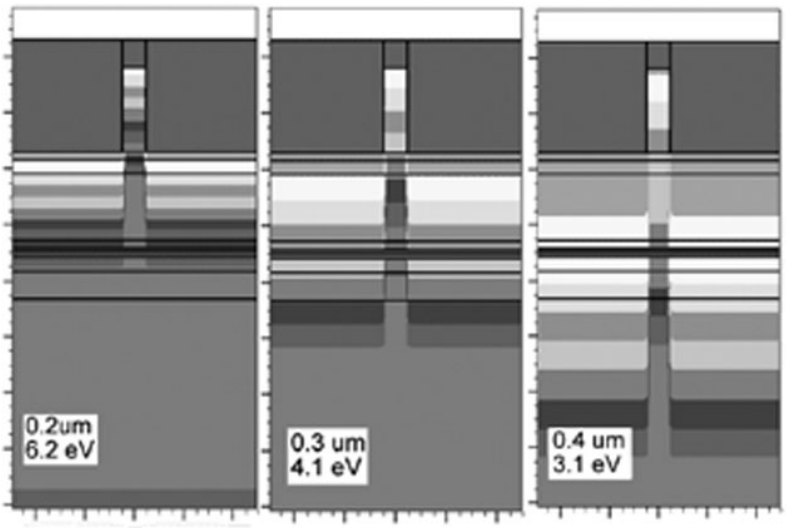

Figure 1. ATLAS photogeneration rate output for a multi-junction solar cell for different light wavelengths.

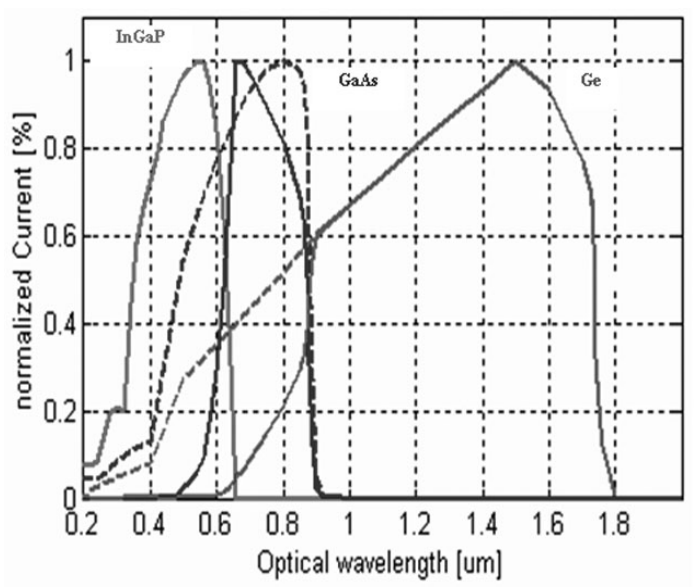

Figure 2. Spectral response of the individual cells (dashed) and of the stacked cell (continuous).

A detailed paper introducing this Novel modeling technique has been previously presented $[9,10]$. 


\section{The Genetic Search Algorithm}

The first step in the optimization process is to maximize the output power of each junction layer individually for several layer thicknesses. These optimum configurations will be used to ensure maximum junction layer output power as junction layer thicknesses are changed during the current-matching process. The junction layer optimization process accepts known materials for the window, emitter, base and back surface field (BSF) and determines the ideal thicknesses and doping levels for each region. The base thickness was chosen to be a dependent variable to achieve a constant overall junction layer thickness. Thus, seven independent variables remain for each overall junction layer thickness. To search all possible solutions rigorously would require an enormous amount of computational time.

Instead, a genetic algorithm [11] was used to search the solution space for the junction layer configuration producing the highest output power.

To enact a genetic algorithm for junction layer optimization, each of the eight variable junction layer parameters was encoded into a fourbit binary string. The encoded binary strings, referred to as genes, were then assembled into 32-bit binary chromosomes.

Figure 3 illustrates the construction of 32-bit binary chromosome from a gene sequence. Each chromosome fully encoded the eight variable properties of a junction layer. A set of 35 ran- domly selected binary strings made up the initial generation of chromosomes. The encoded properties in each of these chromosomes were used to construct and simulate a junction layer ATLAS under AM0 illumination. After the simulation of an entire generation of chromosomes, child chromosomes (to make up the next generation) were formed from a mix of the genes from the best performing parent chromosomes. In addition, the best performing chromosome of each generation was passed unchanged into the next generation.

The genetic search algorithm was allowed to progress for a maximum of 20 generations. This scheme allowed a solution space of over 268 million junction layer designs to be searched to arrive near an optimal junction layer configuration for a specific thickness. Figure 4 demonstrate the improvement in the cell output power.

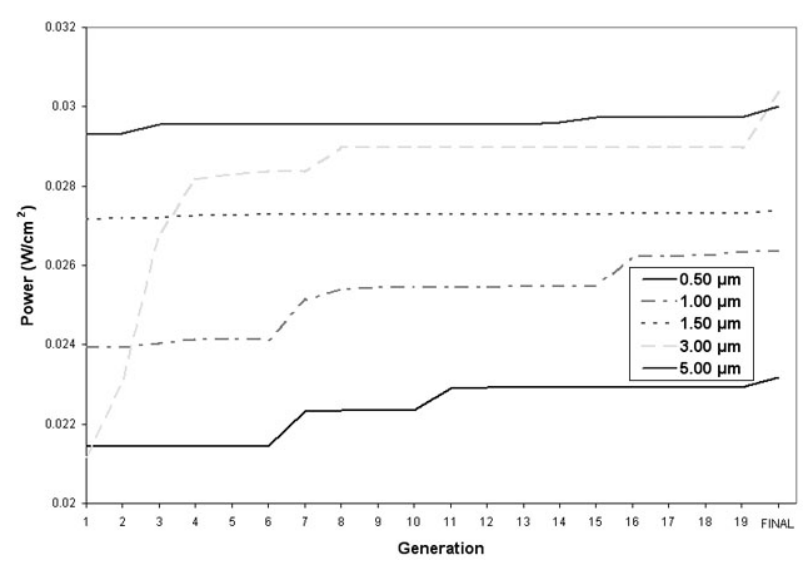

Figure 4. Improving the GaAs junction layer output power.

\begin{tabular}{|c|c|c|c|c|c|c|c|c|c|c|c|c|c|c|c|}
\hline \multirow{2}{*}{\multicolumn{2}{|c|}{$\begin{array}{c}\text { Window } \\
\text { Thickness } \\
\text { Genes }\end{array}$}} & \multirow{2}{*}{\multicolumn{2}{|c|}{$\begin{array}{c}\begin{array}{l}\text { Window } \\
\text { Doping }\end{array} \\
\text { Genes }\end{array}$}} & \multirow{2}{*}{\multicolumn{2}{|c|}{\begin{tabular}{|c|} 
Emitter \\
Thickness \\
Genes \\
\end{tabular}}} & \multirow{2}{*}{\multicolumn{2}{|c|}{$\begin{array}{l}\text { Emitter } \\
\text { Doping } \\
\text { Genes }\end{array}$}} & \multirow{2}{*}{\multicolumn{2}{|c|}{$\begin{array}{c}\text { Base } \\
\text { Thickness } \\
\text { Genes }\end{array}$}} & \multicolumn{2}{|c|}{$\begin{array}{c}\text { Base } \\
\text { Doping }\end{array}$} & \multicolumn{2}{|c|}{$\begin{array}{c}\text { BSF } \\
\text { Thickness }\end{array}$} & \multicolumn{2}{|c|}{$\begin{array}{c}\text { BSF } \\
\text { Doping }\end{array}$} \\
\hline & & & & & & & & & & & nes & & nes & & nes \\
\hline 0 & 0000 & 0 & 0000 & 0 & 0000 & 0 & 0000 & 0 & 0000 & 0 & 0000 & 0 & 0000 & 0 & 0000 \\
\hline 1 & 0001 & 1 & 0001 & 1 & 0001 & 1 & 0001 & 1 & 0001 & 1 & 0001 & 1 & 0001 & 1 & 0001 \\
\hline 2. & 0010 & 2. & 0010 & 2. & 0010 & 2. & 0010 & 2. & 0010 & 2. & 0010 & 2. & 0010 & 2. & 0010 \\
\hline 15 & 1111 & 15 & 11111 & 15 & 1111 & 15 & 1111 & 15 & 1111 & 15 & 11111 & 15 & 1111 & 15 & 1111 \\
\hline
\end{tabular}

Figure 3. Construction of binary chromosomes from gene sequences. 


\section{Iterative Current Matching Routine}

To achieve a maximum overall output current from the full multijunction cell, the current produced by each junction layer needed to be matched to the fullest extent possible. To accomplish this, we used an iterative currentmatching routine beginning with an ATLAS simulation of the full multijunction cell with each junction layer thickness larger than its estimated final thickness. In this initial state, each junction layer absorbed a large amount of light and little light energy was able to penetrate to each lower junction layer successively.

To match short-circuit currents, junction layers were grouped into pairs from the top junction to the substrate junction (Figure 5). Short-circuit currents were matched within the pairs by either increasing or decreasing the thickness of the upper junction layer.

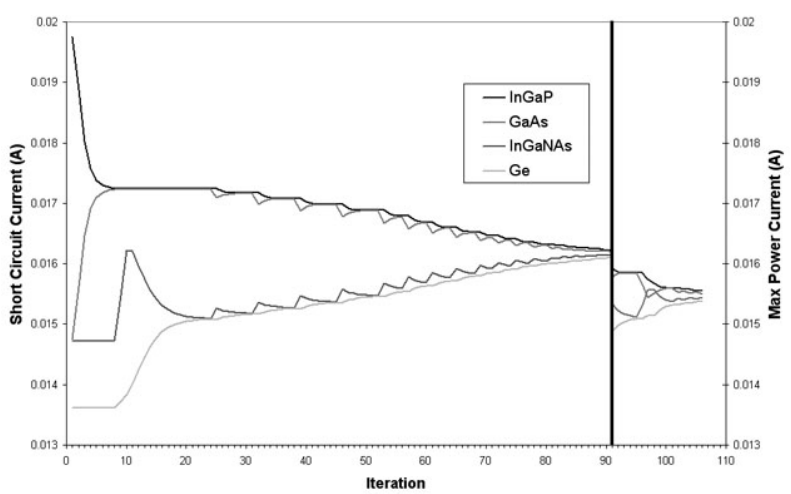

Figure 5. Progress of iterative current matching routine.

Then the junction layers were re-grouped with the other adjacent junction layer and the process repeated iteratively until the short-circuit currents of all junction layers were within $99.6 \%$ of each other. At this point, the routine changed focus to attempt to match the maximum-power currents of the individual junction layers.

The routine ceased when all junction layer maximum-power currents were matched. The optimum cell configuration could then be determined by a review of the output file for the cell with the highest overall maximum power (Figures 6 and 7).

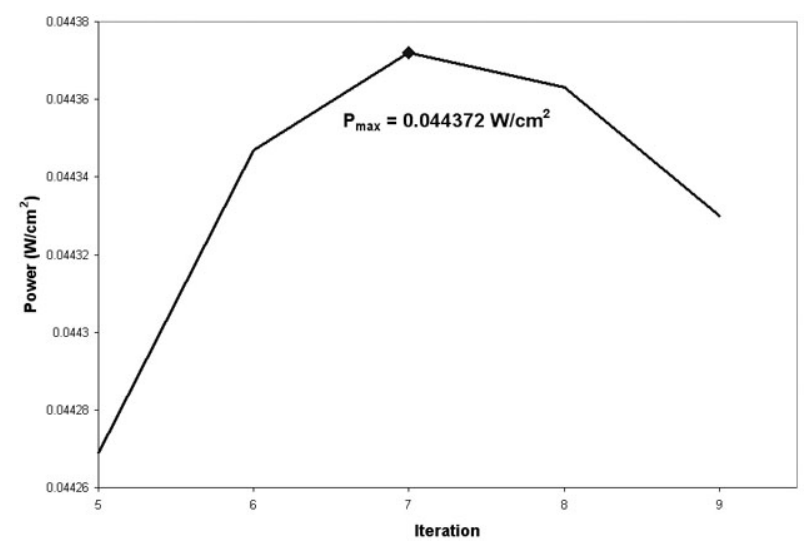

Figure 6. Optimum triple-junction cell output power.

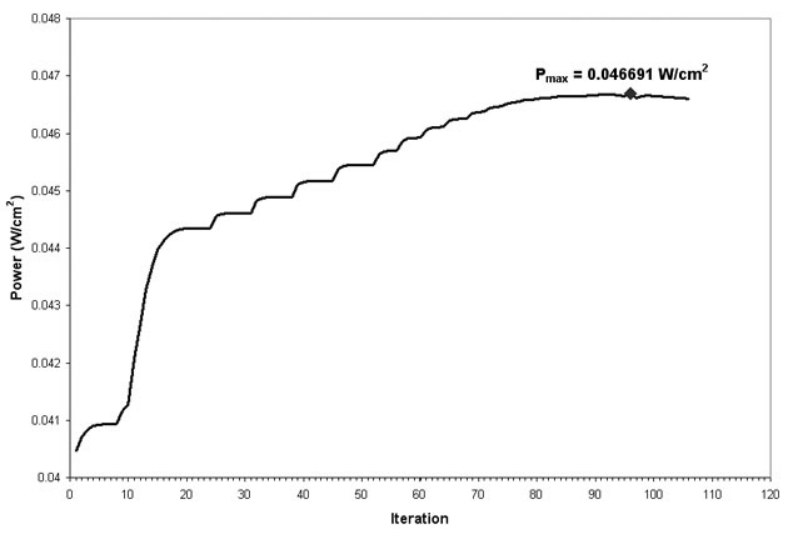

Figure 7. Optimum quad-junction cell output power.

It was necessary to ensure that each junction layer performed optimally at each of the many thicknesses used in the iterative current-matching routine. This was accomplished by using the optimized parameters from the genetic search algorithm for each junction layer. When a junction layer thickness was required that had not been specifically solved for during junction layer optimization, interpolation between known optimum values was used.

\section{Results}

For obvious reasons of propriety, no published reports on the detailed construction of advanced three- and four-junction solar cells could be found. This lack of an experimental baseline complicates any attempt to show the improvement over a tested design obtained by using the optimization procedure proposed in this paper. 


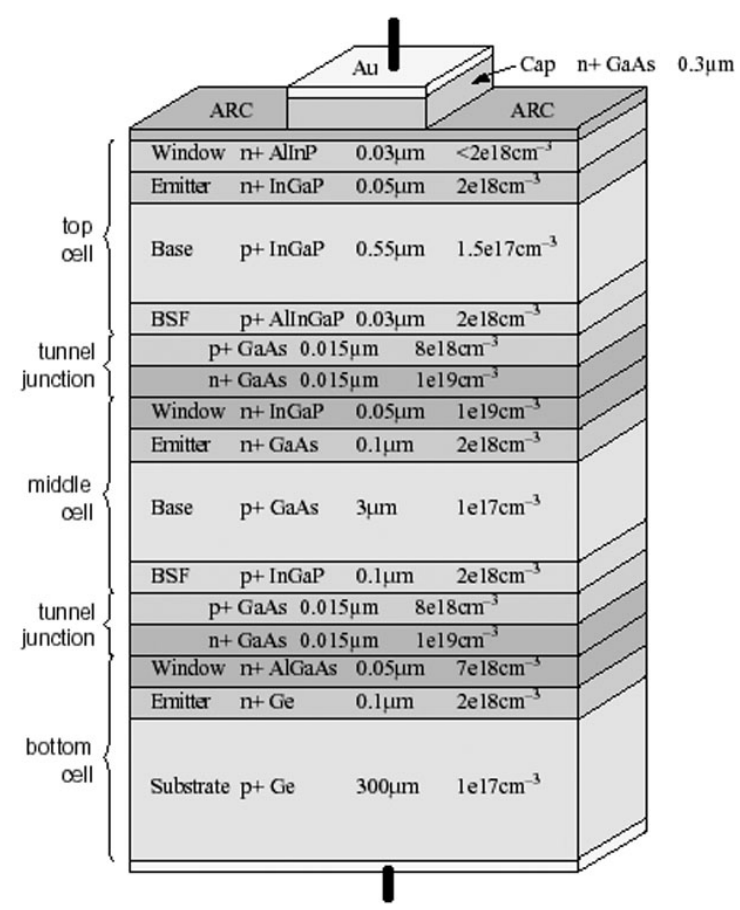

Figure 8. The new optimized triple-junction cell structure.

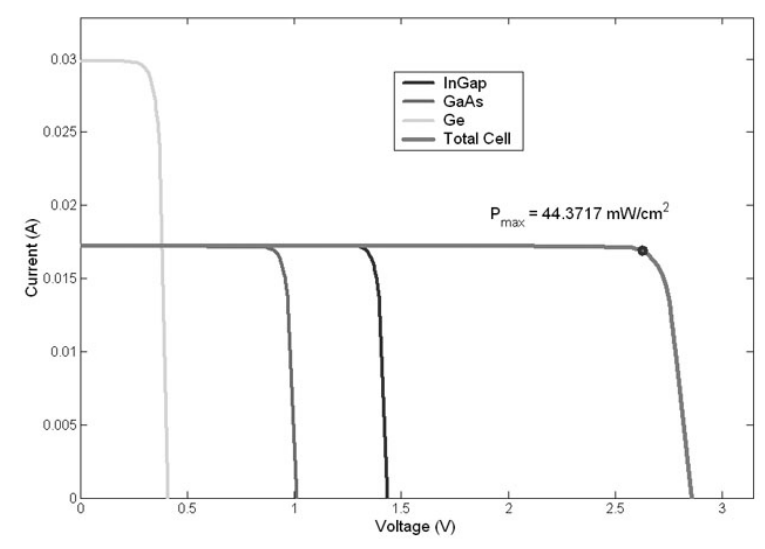

Figure 9. I-V curve for optimized 3-junction.

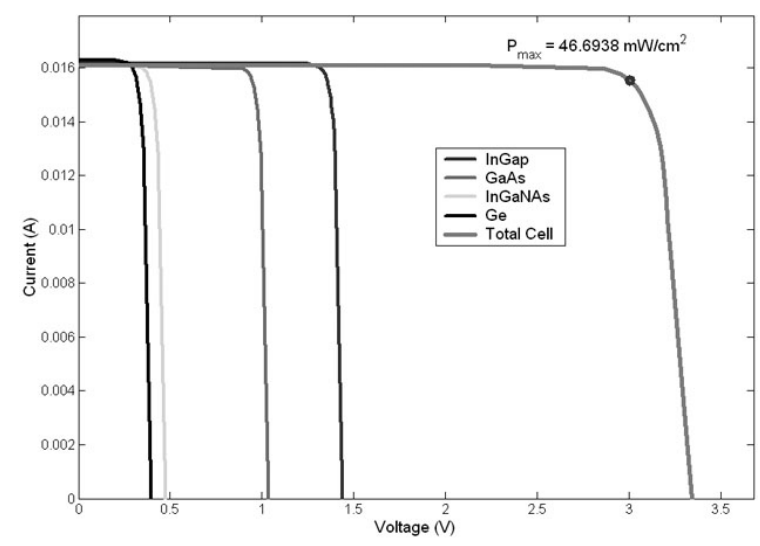

Figure 10. I-V curve for optimized 4-junction.
The advantage of this technique is therefore demonstrated using unpublished three- and fourjunction solar cell designs that have been realized using ATLAS. Figures 8 and 9 illustrate the optimized triple-junction cell structure and its $I-V$ output.

Characteristics of the novel optimized quadjunction $I-V$ are presented in Figure 10, which clearly shows the unprecedented output power achieved using these optimization efforts.

The successful efforts presented here using advanced multi-junction solar cell designs, which achieved devices with record conversion efficiencies, can be similarly used to optimize many solid state devices at a very moderate cost.

\section{References}

[1] R. R. KING, N. H. KARAM, J. H. ERMER, N. HADDAD, P. COLTER, T. ISSHIKI, H. YOON, H. L. COTAL, D. E. Joslin, D. D. Krut, R. Sudharsanan, K. EDMONDSON, B. T. CAVICCHI AND D. R. LILLINGTON, "Next-generation, high-efficiency III-V multijunction solar cells", Proc. Twenty-Eighth IEEE Photovoltaic Specialists Conference, pp. 998-1001, 2000.

[2] T. Agui, T. Takamoto, E. Ikeda, H. Kurita, "High-efficient dual-junction InGaP/GaAs solar cells with improved tunnel interconnect", Proceedings of the International Conference on Indium Phosphide and Related Materials, pp. 203-206, 1998.

[3] S. Kurtz, J. F. GEISZ, D. J. FrIEDMAN, J. M. Olson, A. Duda, N. H. KARAM, R. R. King, J. H. ERMER AND D. E. JOSLIN, "Modeling of electron diffusion length in GaInAsN solar cells", Conf. Record of the Twentyeighth IEEE Photovoltaic Specialists Conference, pp. 1210-1213, IEEE Press, New York, 2000

[4] I. Vurgaftman, J. R. Meyer and L. R. RamMOHAN," "Band parameters for III-V compound semiconductors and their alloys", Applied Physics Review, J. of Applied Physics, Vol. 89, No. 11, pp. 5815-5875, 1 June 2001.

[5] Kinsey, G. S., King, R. R., Edmondson, K. M., Stavrides, A. P., Yoon, H., Fetzer, C. M., Colter, P. C., ERMer, J. H., Gillanders, M. S., Hebert, P., Granata, J. E. AND KARAM, N. H., "Ultra Triple-junction High-efficiency Solar Cells", IEEE AESS Systems Magazine, pp. 8-10, March 2003.

[6] N. H. Karam, R. R. King, M. HAdDAd, J. H. ERMER, H. YoOn, H. L. Cotal, R. Sudharsanan, J. W. ELDREDGE, K. EDMONDSON, D. E. JOSLIN, D. D. KRUT, M. TAKAHASHI, W. NISHIKAWA, M. GILLANDERS, J. GRANATA, P. HERBERT, B. T. CAVICCHI, AND D. R. LiLlington," "Recent developments 
in high-efficiency $\mathrm{Ga}_{0.5} \mathrm{In}_{0.5} / \mathrm{GaAs} / \mathrm{Ge}$ dual- and triple-junction solar cells: steps to next-generation PV cells," Solar Energy Materials \& Solar Cells, Vol. 66, pp. 453-466, 2001.

[7] H. L. COTAL, D. R. LiLlington, J. H. ERMER, R. R. KING, N. H. KARAM, S. R. KURTZ, D. J. FRIEDMAN, J. M. Olsen, J. S. WARD, A. DUDA, K. A. EMERY AND T. MORIARTY, "'Triple-junction Solar Cell Efficiencies Above 32\%: The Promise and Challenges of Their Application in High-Concentration-Ratio PV Systems", Conf. Record of the Twentyeighth IEEE Photovoltaic Specialists Conference, pp. 955960, IEEE Press, New York, 2000.

[8] ATLAS User's Manual, Vols. 1-2, software version 5.6.0.R, Silvaco International, Sunnyvale, CA, 2003.

[9] S. Michael and P. Michalopoulos. "A New Technique for the Development of State-of-theArt Photovoltaic Devices using Silvaco Software," Proceedings of the 6th WSEAS International Multiconference on Circuits, Systems, Communications and Computers(CSCC 2002), Crete, Greece, July 7-14, 2002. pp. 4121-4125.

[10] S. Michael, A. Bates AND M. GReEn, "SilvaCO ATLAS as a Solar Cell Modeling Tool," Proceedings of the $31^{\text {st }}$ IEEE Photovoltaic Specialists Conference, Jan. 3-7, 2005, Orlando, FL, pp. 719-721.

[11] K. F. MAN, K. S. TANG And S. KwOnG, "Genetic Algorithms: Concepts and Applications", IEEE Transactions on Industrial Electronics, Vol. 43, No. 5, pp. 519-534, 1996.
Received: June, 2008 Accepted: September, 2008

Contact address:

Sherif Michael

Department of Elec. \& Comp. Engr. Space Systems Academic Group Naval Postgraduate School Monterey, CA 93943, USA e-mail: michael@nps.edu

SHERIF MICHAEL (IEEE: S'78-M'83-SM'89) received his B.S.E.E. in 1974, the M.S.I.E. \& Ph.D. degrees in 1980 and 1983, respectively, from West Virginia University, Morgantown, WV. He joined the Department of Electrical and Computer Engineering at the Naval Postgraduate School, Monterey CA, in 1983, where he is now a Professor. $\mathrm{He}$ is also one of the founding members of the Space System Academic Group since its initiation in 1985 . His present research interests are in the following areas: modeling design and optimization of multijunction solar cells; radiation and space effects on photovoltaic devices, multi-junction, gallium arsenide (GaAs) and indium phosphide (InP) solar cells, and spacecraft power system design; radiation effects on hardened, mil. spec. devices and design of radiation tolerant ASIC; gallium arsenide (GaAs) and BiCMOS VLSI design; analog circuits design; high speed, high accuracy op amps and applications in A/D. converters; digitally controlled programmable active filters; signal processing: switched capacitor filters; minority carrier and laser annealing of GaAs and InP solar cells; digital circuit design and microprocessor applications.

In over 25 years as a faculty member at NPS, he has served as thesis advisor for more than $90 \mathrm{ECE} /$ Space students. He has more than 100 technical publications in professional journals and international conference proceedings. He organized and chaired the 1998 IEEE International Symposium on Circuits and Systems, in Monterey, CA. He also organized and chaired the $34^{\text {th }}$ Midwest Symposium on Circuits and Systems, in Monterey, CA, in 1991. He is registered as a Professional Engineer. 
